\title{
Economic mechanism of the region breeding service activity
}

\author{
Konstantin Titorenko and Kirill Zhichkin* \\ Samara State Agrarian University, 446442 Kinel, Russian Federation
}

\begin{abstract}
The article examines the concept and elements of the economic mechanism of breeding in the region. The main goal of this work is to determine the features of the economic mechanism of the breeding service in the region for its further optimization. At the same time, the following tasks are being solved: - to reveal the features of the economic mechanism of the breeding service of the region; - to determine the main factors influencing the activities of the breeding service in the region; - to analyze the effectiveness of state support for the breeding service of the region. We note that the technologies of cattle reproduction using the method of artificial insemination with sexed semen and the method of embryo transfer in agricultural enterprises in practice have proven their economic efficiency and high profitability indicators. But to obtain the described results, the source material (sexed seed and embryo), as well as the qualities of the donor and recipient, as well as systematic work in the industry of dairy and beef cattle breeding in the Samara region, are extremely important. Raised cows with high genetic potential, obtained from artificial insemination with sexed semen and embryo transplantation, can then be used as donor cows to obtain embryos and their further transplantation in other agricultural enterprises.
\end{abstract}

\section{Introduction}

Livestock is one of the main branches of agricultural production. At the same time, it was on livestock production that the decline of the nineties and early 2000s was most strongly affected [1-4]. In the conditions of the Samara region, there is a significant reduction in the number of all types of farm animals in comparison with the Soviet period. If in crop production the self-sufficiency of the region is more than $100 \%$, in animal husbandry it is about $50 \%$. Therefore, the role of stimulating measures on the part of the state is increasing [5-8].

The economic mechanism of management is a means of influencing subjects of economic activity through their economic interests for the implementation of economic activities and continuous reproduction processes. [9, 10]

An economic mechanism is a mechanism for the coordination and regulation of economic activity based on the use of a set of economic methods, instruments of influence on economic entities in order to implement the type and scale of reproduction of gross

\footnotetext{
* Corresponding author: zskirill@mail.ru
} 
output necessary in accordance with the changing needs of society through the rational use of available factors of production, timely high-quality reimbursement of their costs in value and in kind. [11-15]

The main structural components of the economic mechanism are systematized in two main directions: market and state regulation. The first group includes demand, supply, price, competition, market infrastructure. The second - state regulation of pricing, subsidies, subsidies, compensation, lending, insurance, taxation, antimonopoly regulation, commodity purchases and interventions, regulation of foreign economic relations. [16]

Based on these definitions, a general diagram of the structure of the economic mechanism of the activity of the tribal service of the region is proposed, shown in Fig. 1. In accordance with this approach, the complex nature of this concept is clearly visible. Therefore, it is necessary to work out methodological approaches to stimulate the activities of the breeding service in the region, taking into account the whole variety of its elements. These methods should implement a multilateral approach to stimulate the economic activity of agricultural producers in the region related to the breeding business and its results.

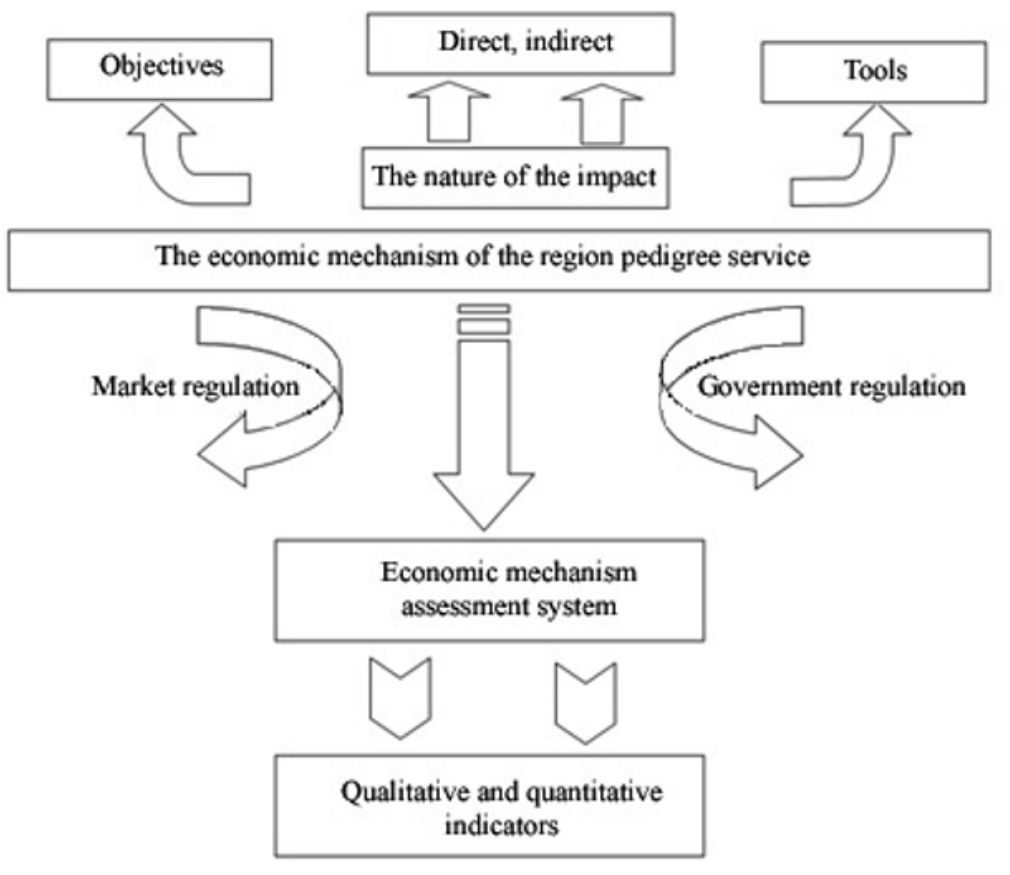

Fig. 1. Generalized structure of the region breeding service economic mechanism.

\section{Methods and materials}

The main goal of this work is to determine the features of the economic mechanism of the breeding service in the region for its further optimization. At the same time, the following tasks are being solved:

- to reveal the features of the economic mechanism of the breeding service of the region;

- to determine the main factors influencing the activities of the breeding service in the region;

- to analyze the effectiveness of state support for the breeding service of the region. 
The object of the research is the economic relations of breeding farms, state bodies regulating breeding, agricultural producers. The research methodology consists in analyzing the features of the economic mechanism of the breeding service of the region, including state support, in relation to the conditions of the Samara region. In the course of the study, the abstract-logical method, situational and system analysis, economic and statistical methods, and the method of expert assessments were used.

\section{Results and discussion}

In the region, there is a decrease in state support for agriculture. If in 2016-2017 the amount of financing of agricultural production reached 6 billion rubles, then at present it is about 4 billion rubles. All articles of state support were reduced, including those for animal husbandry [17-20]. Currently, the size of budget payments is about 1 billion rubles. (Table $1)$.

Table 1. Amounts of financing in the areas of state support, mln rubles.

\begin{tabular}{|l|c|c|c|c|c|c|}
\hline \multirow{2}{*}{ Subsidies } & \multicolumn{3}{|c|}{2018} & \multicolumn{3}{c|}{2019} \\
\cline { 2 - 7 } & $\begin{array}{c}\text { regional } \\
\text { budget }\end{array}$ & $\begin{array}{c}\text { federal } \\
\text { budget }\end{array}$ & total & $\begin{array}{c}\text { regional } \\
\text { budget }\end{array}$ & $\begin{array}{c}\text { federal } \\
\text { budget }\end{array}$ & total \\
\hline $\begin{array}{l}\text { Subsidies for the } \\
\text { development of beef } \\
\text { farming }\end{array}$ & 43.06 & 79.96 & 123.02 & 36.19 & 58.13 & 94.32 \\
\hline $\begin{array}{l}\text { Subsidies to support certain } \\
\text { areas of animal husbandry }\end{array}$ & 74.13 & - & 74.13 & 96.44 & - & 96.44 \\
\hline Feed subsidies & - & - & - & 89.93 & - & 89.93 \\
\hline $\begin{array}{l}\text { Livestock development } \\
\text { subsidies }\end{array}$ & 106.74 & 142.91 & 249.65 & 70.77 & 131.44 & 202.21 \\
\hline $\begin{array}{l}\text { Insurance premium } \\
\text { subsidies }\end{array}$ & 1.78 & 3.31 & 5.09 & 6.22 & 3.33 & 9.55 \\
\hline $\begin{array}{l}\text { Subsidies for increasing } \\
\text { productivity in dairy } \\
\text { farming }\end{array}$ & 179.48 & 71.39 & 250.87 & 202.15 & 71.49 & 273.64 \\
\hline $\begin{array}{l}\text { Subventions to increase } \\
\text { productivity in dairy } \\
\text { farming }\end{array}$ & 322.46 & - & 322.46 & 352.57 & - & 352.57 \\
\hline Total & 727.65 & 297.57 & 1025.22 & 854.27 & 264.39 & 1118.66 \\
\hline
\end{tabular}

As can be seen from the data in the table, the bulk of funding is provided by the regional budget $(70.9 \%$ in 2018, 76.4\% in 2019). The largest share is taken by support aimed at increasing productivity in dairy farming (in total, more than $50 \%$ of the allocated funds).

Table 2. Results of the implementation of measures of state support for animal husbandry.

\begin{tabular}{|l|c|c|c|}
\hline \multicolumn{1}{|c|}{ Indicator } & 2008 & 2019 & $\begin{array}{c}2019 \text { in \% to } \\
2018\end{array}$ \\
\hline $\begin{array}{l}\text { The number of beef cows and crossbred beef cows in } \\
\text { agricultural organizations and peasant farms, thousand heads }\end{array}$ & 24.2 & 25.0 & 103 \\
\hline $\begin{array}{l}\text { Production of beef and veal in live weight in agricultural } \\
\text { organizations and peasant farms, thousand tons }\end{array}$ & 11.9 & 14.8 & 124 \\
\hline Milk herd productivity in agricultural organizations, kg & 5567 & 5920 & 106 \\
\hline $\begin{array}{l}\text { The share of pedigree livestock in the total livestock in } \\
\text { agricultural organizations and peasant farms,\% }\end{array}$ & 9.9 & 10.6 & $+0,7$ \\
\hline $\begin{array}{l}\text { The share of the insured livestock of farm animals in the total } \\
\text { livestock,\% }\end{array}$ & 9.22 & 19.36 & $+10,14$ \\
\hline
\end{tabular}


Based on the data in Table 2, it can be seen that as a result of government support measures, the indicators of the development of livestock farming in the region are increasing. For example, there is an increase in the number of meat animals. For a long time, there was no specialized meat herd in the region, and only in the last 15-20 years the prerequisites for its appearance have been created. There is an increase in the productivity of dairy cattle (by 106\%), which is associated, among other things, with an increase in the proportion of breeding animals with high genetic potential (Table 3).

Table 3. Performance indicators of agricultural organizations - recipients of subsidies for increasing productivity in dairy farming. *

\begin{tabular}{|l|c|c|c|}
\hline \multicolumn{1}{|c|}{ Indicator } & 2008 & 2019 & $\begin{array}{c}2019 \text { in \% } \\
\text { to } 2018\end{array}$ \\
\hline $\begin{array}{l}\text { Share of milk production by recipients of subsidies in the total } \\
\text { volume produced by agricultural organizations of the Samara } \\
\text { region,\% }\end{array}$ & 51.0 & 54.0 & +3.0 \\
\hline Milk production by recipients of this subsidy, thousand tons & 73.1 & 78.0 & 107 \\
\hline Number of dairy cows, thousand heads & 9.7 & 10.1 & 104 \\
\hline Average annual productivity of dairy cows, kg & 7521 & 7748 & 103 \\
\hline
\end{tabular}

* - the recipients of this type of state support are 17 agricultural organizations with a livestock of dairy cows with a productivity of $6000 \mathrm{~kg}$ of milk and above.

Special attention from the leadership of the region is paid to specialized enterprises with high production rates [21-25]. In dairy cattle breeding, a conditional "pool" of 17 enterprises has been formed, with a productivity of more than $6,000 \mathrm{~kg}$ of milk per cow. They receive about a quarter of all funding for the development of livestock in the region. This allows increasing both productivity (on average up to $7748 \mathrm{~kg}$ of milk in 2019) and the share in total milk production (up to 54\%).

The growth of insurance coverage for animals is increasing in the region. Their share increased to $19.36 \%$. Despite the shortcomings of the existing insurance methodology, enterprises are forced to do this due to the deterioration of the epizootic situation in the region (ASF, rabies, brucellosis, etc.) [26].

Despite the growth in livestock production in agricultural organizations and peasant farms, the volume of production in the region practically does not increase. Due to these sources, it is not possible to fully compensate for the decline in production in the private household plots sector [27-29]. Despite the system of subsidies, support for this type of agricultural producers is significantly less compared to other forms of agricultural production. Without equalizing the conditions of state support, it is impossible to reduce the reduction in livestock in private household plots, in the volume of products produced, and to reduce the number of complete abandonment of animals.

The development of the breeding service in the region is characterized primarily by the breeding farms production indicators (Table 4). The productivity of cows in almost all farms is growing, which testifies to the effectiveness of zootechnical measures.

Embryo transplantation is one of the factors behind the dramatic increase in productivity. From an economic point of view, embryo transplantation is especially interesting for commercial farms that do not have breeding animals, but intend to create a breeding nucleus of cattle. For such agricultural enterprises, it is enough to have a broodstock - recipients (outbreds), to whom embryos can be transplanted [30-35].

The rapid development of the biotechnological method for obtaining embryos should be simple and reliable [36-41], allowing with high results to obtain embryos from outstanding cows not only in the Center for Reproductive Technologies, but also in the conditions of the breeding farms of the Samara region. 
Table 4. Breeding sales and milk yield in breeding farms of the Samara region.

\begin{tabular}{|c|c|c|c|c|c|c|c|c|}
\hline \multirow{2}{*}{ Agricultural enterprise } & \multicolumn{3}{|c|}{ Sale of pedigree livestock, hesds } & \multicolumn{5}{c|}{ Milk for 1 cow, kg } \\
\cline { 2 - 10 } & 2014 & 2015 & 2017 & 2018 & 2014 & 2015 & 2017 & 2018 \\
\hline Pedigree plant "Druzhba" & 66 & 70 & 83 & 44 & 6366 & 6422 & 7153 & 7989 \\
\hline Krasnogorskoe & 125 & 142 & 17 & 0 & 5775 & 5780 & 3551 & 4519 \\
\hline Radna & 0 & 90 & 157 & 157 & 7003 & 7007 & 7898 & 6900 \\
\hline Pedigree plant "Kryazh" & 55 & 52 & 55 & 53 & 4417 & 4462 & 5106 & 5802 \\
\hline $\begin{array}{c}\text { Collective farm named after } \\
\text { Kuibyshev }\end{array}$ & 79 & 79 & 73 & 73 & 5200 & 5252 & 5440 & 5713 \\
\hline $\begin{array}{c}\text { Collective farm named after } \\
\text { Kirov }\end{array}$ & 53 & 53 & 53 & 53 & 5949 & 5996 & 6428 & 6507 \\
\hline Severny Klyuch & 100 & 101 & 116 & 116 & 6750 & 6750 & 6776 & 6777 \\
\hline Niva & 48 & 29 & 0 & 0 & 7459 & 8105 & 8868 & 9028 \\
\hline Klondike & 0 & 30 & 28 & 16 & 9224 & 9249 & 9260 & 9277 \\
\hline Usinskoe & 0 & 0 & 44 & 42 & 6886 & 6923 & 6091 & 6687 \\
\hline Total & 526 & 646 & 626 & 554 & 6368 & 6466 & 6755 & 6947 \\
\hline
\end{tabular}

To date, the Samara region does not keep statistics on the number of transplants in the region. But as for the survival rate of embryos, it depends directly on the health of the animals (donor / recipient) and the breed of cattle.

As an example, let us take the experience of cattle embryo transplantation on the basis of Center for Reproductive Technologies (Samara).

This organization began its work on embryo transfer in 2012. The aim of this project was to obtain high-value Holstein bull calves on heifers, first generation black-and-white crossbreeds, as well as to assess the economic efficiency of this method.

The purchase of embryos was carried out at the Osnabrück Livestock Breeding Association (OHG Germany) and their subsequent transfer was carried out with the involvement of OHG specialists. 59 embryos were transferred, resulting in 10 calves and 14 heifers. The gobies were subsequently used to obtain semen at Center for Reproductive Technologies. Thus, the survival rate of embryos in 2012 was $47.4 \%$.

In 2016, 10 more heifers were purchased for embryo transplantation, the first generation crossbreeds of the black-and-white breed. The embryos were also obtained from the Osnabrück Livestock Breeding Association (OHG Germany). The characteristics of the fathers of the purchased embryos are shown in Table 5. In 2016, 4 bulls were received and the survival rate was $50 \%$.

Table 5. Cost-effectiveness of obtaining bulls by embryo transplantation.

\begin{tabular}{|l|c|}
\hline \multicolumn{1}{|c|}{ Indicator } & Value \\
\hline Purchased heifers (1st generation hybrids), heads & 10 \\
\hline Total costs for the purchase of 10 heifers, rubles & 680000 \\
\hline Transplanted embryos, pcs & 10 \\
\hline Cost of 1 purchased embryo, rubles & 30000 \\
\hline Total cost of purchased embryos, rubles & 300000 \\
\hline Received bulls, heads & 4 \\
\hline $\begin{array}{l}\text { Costs for obtaining and raising 4 bulls from the moment of transplantation to the beginning of } \\
\text { obtaining semen (taking into account the proceeds from the sale of 10 heads for meat), rubles }\end{array}$ & 1363626 \\
\hline including 1 bull, rubles & 340906.5 \\
\hline Costs of keeping 1 bull-producer on a bull-barn during the year, rubles & 590000 \\
\hline Average number of cryopreserved doses of semen received from 1 bull per year, rubles & 5100 \\
\hline Cost of selling 1 dose of semen (in 2019 prices), rubles & 270 \\
\hline Planned proceeds from the sale of semen received per year from 1 breeding bull, rubles & 1377000 \\
\hline $\begin{array}{l}\text { The cost of obtaining and raising 1 bull-producer from the moment of transplantation to the } \\
\text { beginning of obtaining semen (taking into account the proceed from the sale of 10 heads for meat) } \\
\text { and its maintenance for 1 year in the bull barn, rubles }\end{array}$ & 930906.5 \\
\hline Expected gross profit (after 1 year of receiving and selling semen from 1 breeding bull), rubles & +446093.5 \\
\hline
\end{tabular}


In September 2019 Center for Reproductive Technologies began to obtain the semen of bull calves obtained by the method of embryo transplantation. As a result, for 1 year of receipt and sale of semen for 1 bull amounted to 446093 rubles. On the basis of the data obtained, the economic efficiency was calculated and the economic benefit from the use of the embryo transplantation method for obtaining high-value breeding bulls - producers of the Holstein breed was experimentally proved.

Nevertheless, I would like to note that the survival rate of embryos directly in Germany, in the Osnabrück Livestock Breeding Association for 2018 averaged 77\%. These results have been achieved thanks to the careful selection of genomically evaluated heifers with high genetic potential and excellent health in Germany as donors.

\section{Conclusion}

In conclusion, we note that the technologies of cattle reproduction using the method of artificial insemination with sexed semen and the method of embryo transfer in agricultural enterprises in practice have proven their economic efficiency and high profitability indicators. But to obtain the described results, the source material (sexed seed and embryo), as well as the qualities of the donor and recipient, as well as systematic work in the industry of dairy and beef cattle breeding in the Samara region, are extremely important. Raised cows with high genetic potential, obtained from artificial insemination with sexed semen and embryo transplantation, can then be used as donor cows to obtain embryos and their further transplantation in other agricultural enterprises.

\section{References}

1. I.A. Hutchinson, L. Shalloo, S.T. Butler, Journal of Dairy Science 96 (10), 6742-6752 (2013) doi: 10.3168/jds.2012-6476

2. A. Lakomiak, K.A. Zhichkin, Journal of Physics: Conference Series 1399, 044088 (2019) doi:10.1088/1742-6596/1399/4/044088

3. K. Zhichkin, V. Nosov, L. Zhichkina, IOP Conference Series: Earth and Environmental Science 337, 012009 (2019) doi:10.1088/1755-1315/337/1/012009

4. V.L. Abramov, F.A. Kodirov, A.A. Gibadullin, V.N. Nezamaikin, O.I. Borisov, N.V. Lapenkova, Journal of Physics: Conference Series 1515, 032025 (2020) doi: 10.1088/1742-6596/1515/3/032025

5. T.A. Baimisheva, I.S. Kurmaeva, Y.Y. Gazizyanova, R.H. Baimeshev, G.A. Aiesheva IOP Conference Series: Earth and Environmental Science 315, 22090 (2019)

6. K.A. Zhichkin, V.V. Nosov, L.N. Zhichkina, A.V. Pavlyukova, L.N. Korobova, IOP Conference Series: Earth and Environmental Science 659, 012005 (2021) doi:10.1088/1755-1315/659/1/012005

7. S. Khayrzoda, D. Morkovkin, A. Gibadullin, O. Elina, E. Kolchina, E3S Web of Conferences 176, 05007 (2020) doi: 10.1051/e3sconf /202017605007

8. S. Bryukhovetskaya, M. Sadriddinov, P. Stroev, A. Gibadullin, M.A. Kirpicheva, Ju. Romanova, Journal of Physics: Conference Series 1515, 032013 (2020) doi: 10.1088/1742-6596/1515/3/032013

9. K. Zhichkin, V. Nosov, L. Zhichkina, V. Panchenko, E. Zueva, D. Vorob'eva, E3S Web of Conferences 203, 05022 (2020) https://doi.org/10.1051/e3sconf/202020305022

10. A. Gibadullin, V. Pulyaeva, T. Usmanova, I. Ivanova, L. Vlasenko, E3S Web of Conferences 164, 11017 (2020) https://doi.org/10.1051/e3sconf /202016411017 
11. K. Zhichkin, V. Nosov, L. Zhichkina, IOP Conference Series: Earth and Environmental Science 403, 012073 (2019) doi:10.1088/1755-1315/403/1/012073

12. K. Zhichkin, V. Nosov, L. Zhichkina, V.Zhenzhebir, S. Rubtsova, E3S Web of Conferences 175, 13008 (2020) https://doi.org/10.1051/e3sconf/202017513008

13. V.V. Nosov, K.A. Zhichkin, L.N. Zhichkina, S.A. Novoselova, N.L. Fomenko, L.P. Bespamjatnova, IOP Conference Series: Earth and Environmental Science 548, 022077 (2020) doi:10.1088/1755-1315/548/2/022077

14. J.M. DeJarnette, R.L. Nebel, C.E. Marshall, Theriogenology 71 (1), $49-58$ (2009) doi: 10.1016/j.theriogenology.2008.09.042

15. D. Morkovkin, I. Hutarava, E. Ogloblina, A. Gibadullin, S. Kharchenko, E3S Web of Conferences 176, 05002 (2020) doi: 10.1051/e3sconf /202017605002

16. C. Maicas, I.A. Hutchinson, J. Kenneally, J. Grant, A.R. Cromie, P. Lonergan, S.T. Butler, Journal of Dairy Science 102 (11), 10530-10542 (2019) doi: 10.3168/jds.201916740

17. S.G. Moore, J.F. Hasler, Journal of Dairy Science 100 (12), 10314-10331 (2017) doi: 10.3168/jds.2017-13138

18. M. Andersson, J. Taponen, M. Kommeri, M. Dahlbom, Reproduction in Domestic Animals 41 (2), 95-97 (2006) doi: 10.1111/j.1439-0531.2006.00625.x

19. K. Oikawa, T. Yamazaki, S. Yamaguchi, H. Abe, H. Bai, M. Takahashi, M. Kawahara, Theriogenology 135, 33-37 (2019) doi: 10.1016/j.theriogenology.2019.06.012

20. S.A. Holden, S.T. Butler, Animal 12 (s1), s97-s103 (2018) doi: 10.1017/S1751731118000721

21. K. Zhichkin, V. Nosov, L. Zhichkina, V. Andreev, T. Mahanova, IOP Conference Series: Earth and Environmental Science 422, 012054 (2020) doi:10.1088/17551315/422/1/012054

22. R.P. Amann, Theriogenology 52 (8), 1441-1457 (1999) doi: 10.1016/S0093691X(99)00229-0

23. K. Zhichkin, V. Nosov, L. Zhichkina, E. Badanin, L. Voloshchuk, O. Kotar, E3S Web of Conferences 217, 09004 (2020) https://doi.org/10.1051/e3sconf/202021709004

24. C. Murphy, L. Shalloo, I.A. Hutchinson, S.T. Butler, Journal of Dairy Science 99 (8), 6680-6692 (2016) doi: 10.3168/jds.2015-10378

25. R.W. Everett, J. Moreno, Large Animal Review 15 (5), 228-230 (2009)

26. P.E Bennemann., F.L. Koller, M.L. Bernardi, I. Wentz, F.P. Bortolozzo, Ciencia Rural 37 (6), 1735-1739 (2007) doi: 10.1590/S0103-84782007000600036

27. E. Karakaya, G. Yilmazbas-Mecitoglu, A. Keskin, A. Alkan, U. Tasdemir, J. Santos, A. Gumen, Reproduction in Domestic Animals 49 (2), 333-337 (2014) doi: 10.1111/rda.12280

28. J. Kurykin, M. Jalakas, T. Kaart, Ü. Jaakma, Veterinarija ir Zootechnika 75 (97), 30-35 (2017)

29. J. Gosálvez, M.A. Ramirez, C. López-Fernández, F. Crespo, K.M. Evans, M.E. Kjelland, J.F. Moreno, Theriogenology 75 (2), 197-205 (2011) doi: 10.1016/j.theriogenology.2010.08.006

30. J.O. Carvalho, R. Sartori, G.M. Machado, G.B. Mourão, M.A.N Dode, Theriogenology 74 (9), 1521-1530 (2010) doi: 10.1016/j.theriogenology.2010.06.030 
31. M.K. Sørensen, J. Voergaard, L.D. Pedersen, P. Berg, A.C. Sørensen, Journal of Animal Breeding and Genetics 128 (4), 267-275 (2011) doi: 10.1111/j.14390388.2011.00924.x

32. A.A. Healy, J.K. House, P.C. Thomson, Journal of Dairy Science 96 (3), 1905-1914 (2013) doi: 10.3168/jds.2012-5465

33. H. Steele, D. Makri, W.E. Maalouf, S. Reese, S. Kölle, Scientific Reports 10 (1), 6255 (2020) doi: 10.1038/s41598-020-63077-6

34. S. Joezy-Shekalgorabi, A. Maghsoudi, M.R. Mansourian, Italian Journal of Animal Science 16 (4), 666-672 (2017) doi: 10.1080/1828051X.2017.1321473

35. J.L. Schenk, T.K. Suh, Jr.G.E. Seidel, Theriogenology 65 (2), 299-307 (2006) doi: 10.1016/j.theriogenology.2005.04.026

36. J.D.O. Carvalho, R. Sartori, L. Rodello, G.B. Mourão, S.D. Bicudo, M.A.N. Dode, Livestock Science 207, 30-37 (2018) doi: 10.1016/j.livsci.2017.11.005

37. G.A. Palma, F. Sinowatz, Journal of Veterinary Medicine Series C: Anatomia Histologia Embryologia 33 (5), 257-262 (2004) doi: 10.1111/j.14390264.2004.00543.x

38. K. Titorenko, K. Zhichkin, IOP Conference Series: Earth and Environmental Science 677, 052074 (2021) doi:10.1088/1755-1315/677/5/052074

39. J.M. DeJarnette, M.A. Leach, R.L. Nebel, C.E. Marshall, C.R. McCleary, J.F. Moreno, Journal of Dairy Science 94 (7), 3477-3483 (2011) doi: 10.3168/jds.2011-4214

40. H. Hayakawa, T. Hirai, A. Takimoto, A. Ideta, Y. Aoyagi, Theriogenology 71 (1), 6873 (2009) doi: 10.1016/j.theriogenology.2008.09.016

41. I. Kaimio, M. Mikkola, H. Lindeberg, J. Heikkinen, J.F. Hasler, J. Taponen, Theriogenology 80 (8), 950-954 (2013) doi: 10.1016/j.theriogenology.2013.07.025 